\title{
Retention of Motility, Viability and Penetrating Ability of Acrosome-Reacted Goat Spermatozoa
}

\author{
Hiroshi Kusunoki, Morito Sakaue*, Hiroshi Harayama, \\ Seishiro Kato* and Sunao KANDA* \\ The Graduate School of Science and Technology, and \\ ${ }^{*}$ Faculty of Agriculture, Kobe University, Kobe-shi 657
}

(Received November 13, 1989)

\begin{abstract}
The retention of the motility and viability of acrosome-reacted goat spermatozoa and their ability to penetrate zona-free hamster eggs was investigated. Effects of caffeine and imidazole on these parameters were also examined. Ejaculated goat spermatozoa were washed and preincubated in $\mathrm{K}-3$ medium in sealed glass tubes at $39.5^{\circ} \mathrm{C}$ for $2 \mathrm{~h}$ to induce the acrosome reaction. This was followed by resuspension in $\mathrm{BO}$ medium, BO medium with caffeine and $\mathrm{BO}$ medium with imidazole and incubated at $37^{\circ} \mathrm{C}$ for $5 \mathrm{~h}$. During incubation, sperm motility and viability were assessed at one hour intervals. The acrosome-reacted cells after resuspension in BO medium or BO medium with imidazole and those incubated for $3 \mathrm{~h}$ in these media were further incubated with zona-free hamster eggs at $37^{\circ} \mathrm{C}$. During incubation with the eggs, time-related changes in egg penetration were examined. The following results were obtained: 1) The motility patterns of goat spermatozoa before and after the acrosome reaction were different. Acrosome-reacted goat spermatozoa exhibited 'whiplash' motility. 2) The motility and viability of goat cells after the acrosome reaction were remarkably lower than those before the reaction. 3) The ability of acrosome-reacted goat spermatozoa to penetrate zona-free hamster eggs was retained for as much as $3 \mathrm{~h}$. 4) The addition of imidazole to sperm suspension promoted the maintenance of motility and viability of acrosome-reacted goat spermatozoa and prolonged the retention of their ability to penetrate zona-free hamster eggs. The addition of caffeine was effective for the temporary activation of the motility but made difficult the maintenance of motility and viability.
\end{abstract}

Jpn. J. Zootech. Sci., 61 (7) : 640-647, 1990

Key words: Acrosome-reacted goat sperm, whiplash motility, viability, penetrating ability, imidazole

Mammalian spermatozoa progressively undergo various changes from release into the seminiferous tubules lumen to fertilization in a female. These changes roughly occur in two stages. The first stage is during sperm passage through the male reproductive tract, especially the epididymis, and the second, during residence in the female reproductive tract. These stages are named 'maturation' and 'capacitation and the acrosome reaction', respectively. The characteristics of immature spermatozoa in the seminiferous tubules and efferent ducts, and those of maturing spermatozoa during epididymal transit and ejaculated spermatozoa following maturation have long been studied in various mammalian species including the goat ${ }^{1}$. To our knowledge, however, there are few reports on the characteristics of cells having undergone capacitation and the acrosome reaction which occur in the 
female tract. Apparently for this reason, although it is easy to obtain enough spermatozoa to assess the former cases, it is difficult to do so in the latter. Recently, the authors ${ }^{2-4}$ developed a method for inducing the acrosome reaction in ejaculated goat spermatozoa. In the present study, the retention of the motility and viability of goat spermatozoa and their ability to penetrate zona-free hamster eggs following the acrosome reaction induced by this method were examined. The effects of imidazole and caffeine on these parameters were also studied.

Capacitation and the acrosome reaction are considered two distinct events, the former being prerequisite for the latter. Whether spermatozoa display the acrosome reaction can be easily determined since this reaction results in morphological change in the sperm head. But it is difficult to determine the occurrence of capacitation since this is a functional or physiological change in cells not accompanied by morphological change. In this research the authors could not determine whether spermatozoa undergo capacitation prior to the acrosome reaction.

\section{Materials and Methods}

The medium used for washing spermatozoa and inducing the acrosome reaction was a $\mathrm{K}-3$ medium $^{4)}$ containing $125.83 \mathrm{mM} \mathrm{NaCl}, 2.25 \mathrm{mM}$ $\mathrm{CaCl}_{2}$ and $37.00 \mathrm{mM} \mathrm{NaHCO}$. Two mature Shiba goats (Japanese Native) were used for the source of semen. Spermatozoa collected with an artificial vagia were washed three times by centrifugation for $5 \mathrm{~min}$ at $600 \times \mathrm{g}$ and resuspended in the medium to give a high concentration $\left(3.0-4.0 \times 10^{9}\right.$ cells $\left./ \mathrm{ml}\right)$. A portion of the sperm suspension was preincubated in a sealed glass tube at $39.5^{\circ} \mathrm{C}$ for $2 \mathrm{~h}$ to induce the acrosome reaction. Sperm preincubation in sealed glass tubes was performed as described in our previous reports ${ }^{2-4}$.

In the first series of experiments, for comparison of sperm motility and viability before and after the acrosome reaction, only washed spermatozoa and preincubated spermatozoa were resuspended in BRACKETT-OLIPHANT (BO) medium $^{5)}$; containing $112.00 \mathrm{mM} \mathrm{NaCl}, 4.02$ $\mathrm{mM} \mathrm{KCl}, 2.25 \mathrm{mM} \mathrm{CaCl}_{2}, 0.83 \mathrm{mM} \mathrm{NaH}_{2} \mathrm{PO}_{4}$,

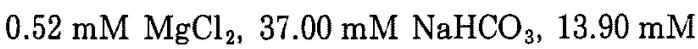
glucose, $1.25 \mathrm{mM}$ sodium pyruvate, $3 \mathrm{mg}$ bovine serum albumin $/ \mathrm{ml}$ and $50 \mu \mathrm{g}$ penicillin $\mathrm{G}$ (potassium salt) $/ \mathrm{ml}$, at about $3.0 \times 10^{8}$ cells $/ \mathrm{ml}$ and incubated at $37^{\circ} \mathrm{C}$ for $5 \mathrm{~h}$. During incubation, sperm motility and viability were assessed at intervals of one hour.

In the second series of experiments in which the effects of caffeine and imidazole on sperm motility and viability were examined, preincubated spermatozoa were resuspended in $\mathrm{BO}$ medium, BO medium with $2 \mathrm{mM}$ caffeine and $\mathrm{BO}$ medium with $10 \mathrm{mM}$ imidazole at about 3.0 $\times 10^{8}$ cells $/ \mathrm{m} l$ and incubated at $37^{\circ} \mathrm{C}$ for $5 \mathrm{~h}$. During incubation, the motility and viability were assessed at intervals of one hour.

Sperm motility was assessed microscopically at $37^{\circ} \mathrm{C}$. For evaluating the motility pattern of each cell, spermatozoa were photographed at $37^{\circ} \mathrm{C}$ with NEOPAN 400 PRESTO (Fuji photo film CO., LTD.) at an exposure period of one second under dark-field illumination. Sperm viability and the acrosome reaction were estimated by the trypan blue-Giemsa (TG) method $^{6)}$. Live spermatozoa were determined by trypan blue exclusion in the postacrosomal region; and the integrity of the acrosome was determined based on a reddish-purple appearance of the intact acrosome after exposure to the Giemsa solution. Sperm counting was made for 200 to 300 cells in the microscopic field selected at random. The percentages of motile cells and live cells were subjected to analysis of variance after arc-sine transformation. When the treatment effects were significant, individual means were further tested by DUNCAN's new multiple range test ${ }^{7}$.

In the third series of experiments, to investigate the retention of ability of acrosomereacted goat sperm to penetrate zona-free 
hamster eggs and the effects of imidazole on retentivity, preincubated spermatozoa were resuspended in $\mathrm{BO}$ medium and $\mathrm{BO}$ medium with $10 \mathrm{mM}$ imidazole at about $3.0 \times 10^{8}$ cells $/ \mathrm{m} l$ and incubated at $37^{\circ} \mathrm{C}$ for 0 or $3 \mathrm{~h}$. Following this, spermatozoa were further incubated with zona-free hamster eggs at $37^{\circ} \mathrm{C}$ for $5 \mathrm{~h}$. During this time, time-related changes in the penetration of the eggs by spermatozoa were examined. The preparation of zona-free hamster eggs, insemination, incubation and examination of sperm penetration were all conducted according to the method described previously ${ }^{3)}$. To make uniform the retention of fertilizing ability of hamster eggs, all eggs were collected from the ampullae of the oviduct $17 \mathrm{~h}$ after hCG administration. The results of the first series of the experiments indicated that the percentage of live acrosomereacted cells was apparently lower in the sample incubated for $3 \mathrm{~h}$ than for $1 \mathrm{~h}$. Thus, the sperm concentration of the sample incubated for $3 \mathrm{~h}$ at insemination time $\left(4-6 \times 10^{7}\right.$ cells $/ \mathrm{m} l$ ) was four to six times that of the sample incubated for $1 \mathrm{~h}\left(1 \times 10^{7}\right.$ cells $\left./ \mathrm{m} l\right)$. The statistical significance of the proportion of zona-free hamster eggs penetrated by goat cells and total number of male pronuclei in the vitellus of these eggs determined by hamster tests using various sperm samples were evaluated by the chi-squared method. That of average number of goat cells in the vitellus of penetrated eggs was determined using DuNCAN's new multiple range test ${ }^{7}$ or t-test.

\section{Results}

In the first series of experiments, a comparison was made of the motility and viability of goat spermatozoa before and after the acrosome reaction. After washing, about $80 \%$ of the spermatozoa in the sample vigorously advanced. However, few of them underwent the acrosome reaction. Following preincubation to induce the acrosome reaction, although the percentage of live cells fell to $65 \%$, most
$(64 \%)$ of them underwent the reaction. The motility patterns of these acrosome-reacted cells photographed at an exposure of one second under dark-field illumination are shown in Figs. 1 and 2. For examination, a small portion of sperm suspension was placed on prewarmed glass slides and covered with cover glasses as the preparation. At that time, the acrosome-reacted cells were attached either to the slide or coverslip in the region of the equatorial segment. The acrosome-reacted cells following preincubation showed only feeble tail shaking (Fig. 1). However, af ter being resuspended in the $\mathrm{BO}$ medium, their tails showed whiplash movement (Fig. 2). This beat pattern was asymmetrical, causing extreme flexion of the neck region. Changes in motility and viablity of spermatozoa before and after the acrosome reaction during incubation in the BO medium are given in Fig. 3. Before the reaction, neither changed significantly during incubation. Both these parameters following the reaction lessened significantly with incubation time $(P<0.05)$, and the percentage of live cells in the sample incubated for $5 \mathrm{~h}$ decreased to $<10 \%$. Fig. 3 also implies that although most of the live cells identified by the TG method were motile in the sample incubated for $<1 \mathrm{~h}$, nearly $80 \%$ and $60 \%$ were motile in the sample incubated for 2 and $3 \mathrm{~h}$ respectively. The number of immotile live cells tended to increase with the time of incubation.

In the second series of experiments, the effects of caffeine and imidazole on motility and viability of acrosome-reacted goat spermatozoa were examined. The results are summarized in Fig. 4. During a few hours of incubation, more vigorous motility was observed for spermatozoa resuspended in the medium with caffeine than for those resuspended in the other media. Regardless of which medium, the percentages of motile and live cells significantly decreased with the time of incubation $(\mathrm{P}<0.05)$. In particular, the percentage of motile cells fell rapidly in the 


\section{Goat Sperm Life after Acrosome Reaction}

medium containing caffeine. Of the three media, at any preincubation time, the percentages of motile and live cells in the sample incubated in BO medium as the control exceeded those in the $\mathrm{BO}$ medium with caffeine but less than those in the medium containing
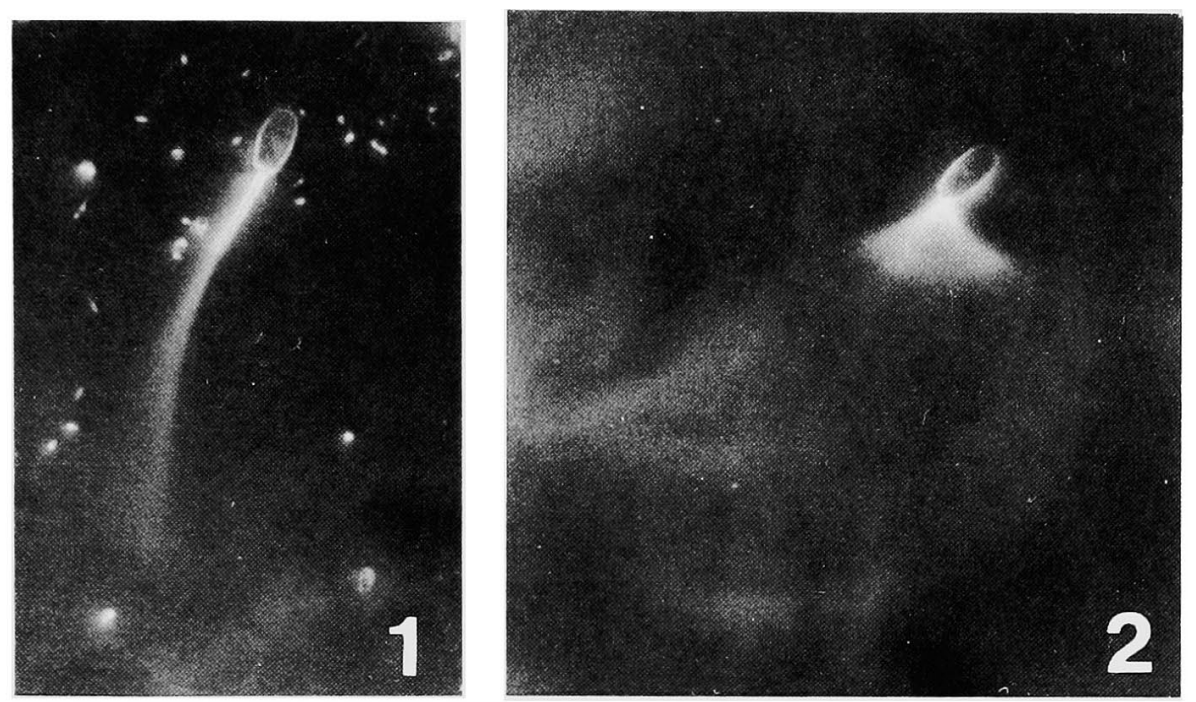

Explanation of Figures

Goat spermatozoa were washed three times with $\mathrm{K}-3$ medium and resuspended in the medium. To induce the acrosome reaction, they were introduced into sealed glass tubes and preincubated at $39.5^{\circ} \mathrm{C}$ for $2 \mathrm{~h}$. They were then recovered from the glass tubes (Fig. 1) and resuspended in BO medium (Fig. 2). The spermatozoa were photographed at an exposure period of one second under dark-field illumination.

Fig. 1. Spermatozoon with trembling tails. Original magnification, $\times 400$.

Fig. 2. Spermatozoon exhibiting 'whiplash' motility. Original magnification, $\times 400$.

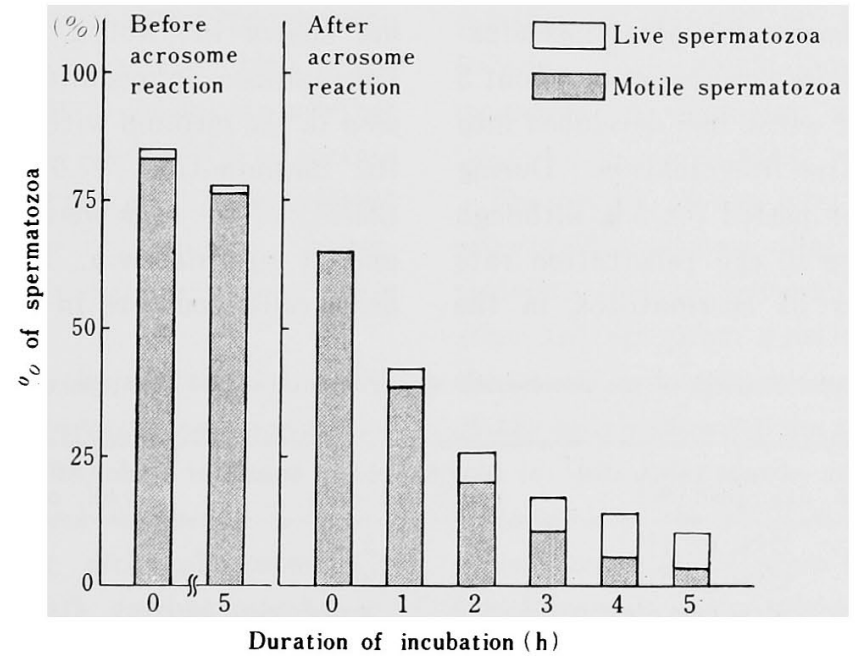

Fig. 3. Comparison of the motility and viability of goat spermatozoa before and after the acrosome reaction $(n=6)$. 


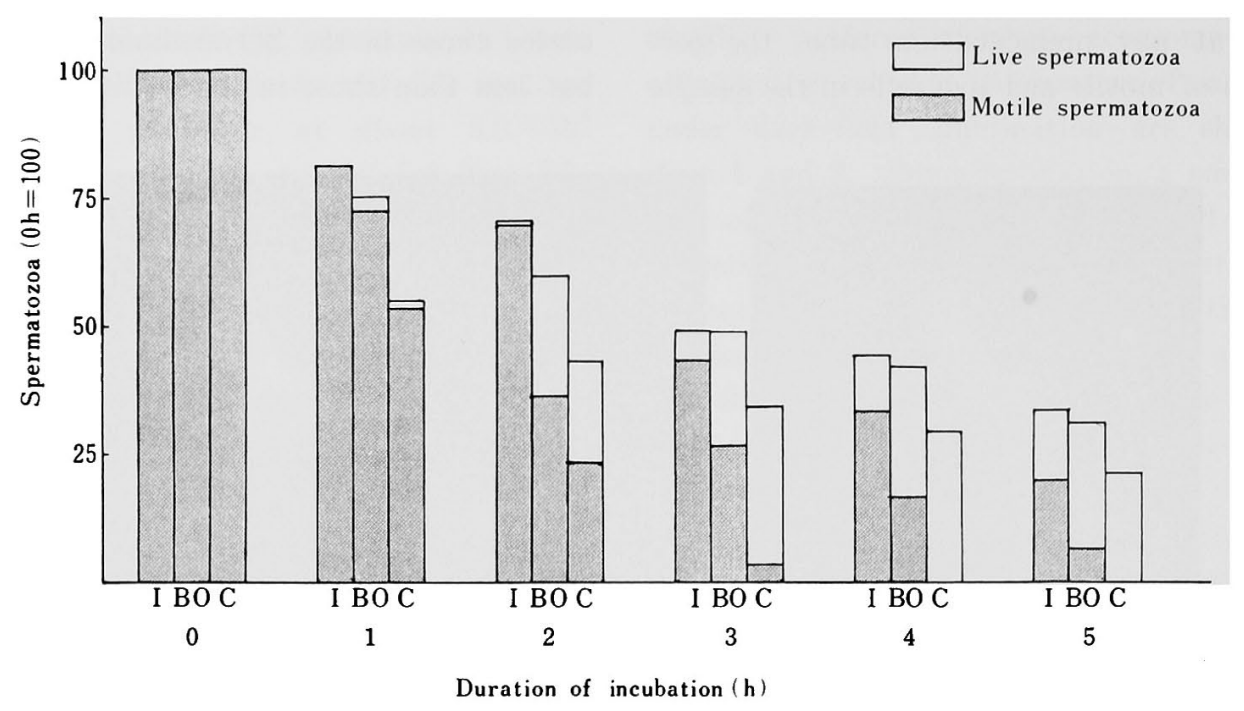

Fig. 4. Effects of caffeine and imidazole on the motility and viability of acrosome-reacted goat spermatozoa $(n=4)$.

$\mathrm{BO}$; BO medium (Control), I ; BO medium with 10-mM imidazole, C ; BO medium with 2-mM caffeine

imidazole.

The results obtained in the third series of experiments are given in Table 1. About $61 \%$ of the eggs picked up at $1 \mathrm{~h}$ after insemination had been penetrated by about 2 spermatozoa, all at the stage of head enlargement. Most $(84.2 \%)$ of the eggs had been penetrated by about 4 spermatozoa, $10 \%$ of which had developed into male pronuclei, $2 \mathrm{~h}$ after insemination. All the eggs were penetrated by about 5 spermatozoa, $31 \%$ of which had developed into the pronuclei, $3 \mathrm{~h}$ after insemination. During subsequent incubation period for $5 \mathrm{~h}$, although no significant change in egg penetration rate and average number of spermatozoa in the vitellus of these penetrated eggs occurred, the number of male pronuclei in the vitellus increased.

Next, acrosome-reacted cells immediately after resuspended in $\mathrm{BO}$ medium with and without imidazole and those incubated for $3 \mathrm{~h}$ in each medium were further incubated with zona-free hamster eggs for $5 \mathrm{~h}$. The results are shown in Table 2. In the case of using spermatozoa immediately following resuspension in the medium with and without imidazole for insemination, $97.0 \%(32 / 33)$ and $74.2 \%$ $(23 / 31)$ of the eggs were penetrated by about 2 and 3 spermatozoa, respectively. However, using cells incubated in BO medium, none of 45

Table 1. Time-related changes of the penetration of acrosome-reacted goat spermatozoa into zona-free hamster eggs

\begin{tabular}{cccc}
\hline $\begin{array}{c}\text { Time after } \\
\text { insemination }(h)\end{array}$ & $\begin{array}{l}\text { No. of eggs penetrated/ } \\
\text { no. examined [\%] }\end{array}$ & $\begin{array}{l}\text { Average no. of sperm in } \\
\text { penetrated eggs }\end{array}$ & $\begin{array}{c}\text { No. of enlarged sperm heads[\%] } \\
\text { +no. of male pronuclei [\%] }\end{array}$ \\
\hline 1 & $22 / 36[61.1]^{\mathrm{c}}$ & $2.1^{\mathrm{b}}$ & $46[100]+0[0]$ \\
2 & $32 / 38[84.2]^{\mathrm{b}}$ & $4.3^{\mathrm{a}}$ & $122[90]+14[10]^{\mathrm{c}}$ \\
3 & $29 / 29[100.0]^{\mathrm{a}}$ & $4.6^{\mathrm{a}}$ & $92[69]+42[31]^{\mathrm{b}}$ \\
4 & $24 / 24[100.0]^{\mathrm{a}}$ & $4.8^{\mathrm{a}}$ & $69[60]+46[40]^{\mathrm{b}}$ \\
5 & $29 / 29[100.0]^{\mathrm{a}}$ & $4.5^{\mathrm{a}}$ & $79[47]+88[53]^{\mathrm{a}}$ \\
\hline
\end{tabular}

$\mathrm{a}, \mathrm{b}, \mathrm{c}$ Values within the same column with different superscripts differ significantly, $\mathrm{P}<0.05, \mathrm{n}=4$. 
Table 2. Effect of imidazole on the retention of the ability of acrosome-reacted goat spermatozoa to penetrate zona-free hamster eggs

\begin{tabular}{cccc}
\hline $\begin{array}{l}\text { Incubation time before } \\
\text { insemination }(h)\end{array}$ & $\begin{array}{l}\text { With(+) or without (-) } \\
\text { imidazole }\end{array}$ & $\begin{array}{l}\text { No. of eggs penetrated/ } \\
\text { no. examined [\% }]\end{array}$ & $\begin{array}{l}\text { Average no. of sperm in } \\
\text { penetrated eggs }\end{array}$ \\
\hline 0 & - & $23 / 31[74.2]$ & 1.6 \\
\cline { 2 - 4 } & + & $32 / 33[97.0]^{*}$ & $2.8^{*}$ \\
\hline 3 & - & $0 / 45[0.0]$ & - \\
\hline
\end{tabular}

$* P<0.05$ compared with values without imidazole.

eggs was penetrated. With cells incubated in the presence of imidazole, $19.6 \%(10 / 51)$ of the eggs were penetrated by one spermatozoon.

\section{Discussion}

The first series of experiments indicate that the motility patterns of goat spermatozoa differ before and after the acrosome reaction. YANAGIMACHI $^{8)}$ was the first to report that after capacitation hamster spermatozoa undergo the acrosome reaction and their motility patterns change. He termed the motility pattern(s) peculiar to spermatozoa following capacitation 'hyperactivated motility'. Since then essentially the same has been found for guinea pig $^{9-13)}, \operatorname{dog}^{14}$, mouse ${ }^{15-17)}$, rabbit ${ }^{18-20)}$, ram $^{21,22)}$, bat ${ }^{23)}$ and dolphin ${ }^{24)}$ spermatozoa after capacitation. The motility pattern(s) observed in acrosome-reacted goat spermatozoa in the present study was similar to that in the cells of these species. It is not known whether 'hyperactivated motility' is limited to certain species or is a general phenomenon throughout the mammals ${ }^{25)}$. However, possibly, 'hyperactivated motility' is a common phenomenon to the goat.

In the present study, 'hyperactivated motility' was observed in spermatozoa resuspended in $\mathrm{BO}$ medium ${ }^{5)}$ but not in $\mathrm{K}-3$ medium ${ }^{4)}$ used for inducing the acrosome reaction. YANAGI$\mathrm{MACHI}^{26)}$ reported that although guinea pig spermatozoa treated with various membraneactive reagents showed both the acrosome reaction and 'hyperactivated motility' within several minutes, spermatozoa treated under the same conditions but without exogenous energy sources underwent the acrosome reaction without 'hyperactivated motility' and were weakly motile. However, they began typical hyperactivated movement after addition of pyruvate. FrASER and QUiNN ${ }^{27)}$ reported that mouse spermatozoa required glucose to initiate 'hyperactivated motility'. In contrast to the compositions of the two media used in the present study, the $\mathrm{K}-3$ medium was found to contain no energy substrates. Thus, the main reason why spermatozoa failed to exhibit 'hyperactivated motility' in K-3 medium may possibly be the absence of energy substrates in it. In preliminary experiments, the motility of goat spermatozoa both before and after the acrosome reaction was noted to rapidly decrease in the K-3 medium. The energy for motility is provided by respiration and glycolysis. Thus, spermatozoa may possibly be incapable of acquiring sufficient energy for 'hyperactivated motility' in a $\mathrm{K}-3$ medium.

The results of the first and third series of experiments showed that both motility and viability of goat spermatozoa were much less after the acrosome reaction than before, and the ability to penetrate zona-free hamster eggs of the cells following the reaction was retained up to $3 \mathrm{~h}$. Fleming and YanAGIMACHI ${ }^{28)}$ reported that the abilities of acrosome-reacted guinea pig spermatozoa to fuse the plasma membranes of guinea pig and hamster eggs and to pass through the zonae pellucidae of guinea pig eggs were retained for as long as $8-9 \mathrm{~h}$ and $2 \mathrm{~h}$, respectively. Thus, the time of retention 
of this ability appears less in goat than in guinea pig. In the sea urchin, spermatozoa are reported to lose fertilizing capacity within a few minutes after the acrosome reaction ${ }^{29,30)}$. The retention time of the fertilizing capacity of spermatozoa after the acrosome reaction may vary according to animal species but be much shorter in all species.

The results of the second and third series of experiments indicated that the addition of imidazole to sperm suspension was effective for mainitaining motility and viability of acrosome-reacted goat spermatozoa and prolonging the retention of their ability to penetrate zona-free hamster eggs. The addition of caffeine was effective for the temporary activation of motility but rather adversely affected the maintenance of motility and viability. The same effect of caffeine as noted in the present study has been reported ${ }^{31)}$ on the motility of goat spermatozoa treated with ionophore A 23187. HANADA ${ }^{32)}$ reported that, in hamster tests with goat spermatozoa preincubated in uteri isolated from rabbits, when imidazole was added to a sperm suspension and the medium for incubation with eggs, the number of eggs penetrated by goat cells was significantly increased. Caffeine has been confirmed to inhibit the hydrolytic action of phosphodiesterase on adenosine- $3^{\prime}: 5^{\prime}$-cyclic monophosphate (cAMP) and increase the content of cAMP in cells ${ }^{33)}$. Imidazole has the effect opposite, stimulating the activity of this phosphodiesterase ${ }^{34)}$. The relation between these effects on sperm motility and viability as noted in the present study and reagent properties is poorly understood.

The present data indicate that the life of spermatozoa following the acrosome reaction is quite short. But possibly, some unknown factor present in vivo is responsible for this. For example, rabbit spermatozoa can generally capacitate by at least $5-h$ residence in the female reproductive tract ${ }^{35)}$. However, SEITz et $a l_{.}{ }^{36)}$ found that rabbit spermatozoa recov- ered from uterus $36 \mathrm{~h}$ after mating were still capable of fertilizing eggs. It thus appears that in the female reproductive tract, the time of the occurrence of capacitation and the acrosome reaction is unique for each spermatozoon and eggs are supplied with fertilizing spermatozoon successively following the first appearance of a capacitated and acrosomereacted spermatozoon.

\section{References}

1) Yanagimachi, $R$., in The Physiology of Reproduction, vol. 1. (KNoBIL, E. and J.D. NEL, eds.) 135-185. Raven Press. New York. 1988.

2) Kusunoki, H., M. Sakaue, S. Kato and S. Kanda, Jpn. J. Anim. Reprod., 34 : 225-235. 1988.

3) Kusunoki, H., M. SAKaue, S. Kato and S. Kanda, J. Exp. Zool., 249 : 322-328. 1989.

4) Kusunoki, H., S. Kato and S. KANDA, J. Exp. Zool., 250 : 346-348. 1989.

5) Brackett, B.G. and G. OLiPiant, Biol. Reprod., 12 : 260-274. 1975.

6) Kusunok1, H., M. SaKatee, H. Harayama, S. Kato and S. KANDA, Jpn. J. Zootech. Sci., 59: 235-240. 1988.

7) SteEl, R.G.D. and J.H. Torrie, Principles and Procedures of Statistics. McGraw-Hill Book Co., New York. 1960.

8) Yanagimachl, R., J. Reprod. Fertil., 23 : 193-196. 1970.

9) Yanagimachi, R., Anat. Rec., 174 : 9-20. 1972.

10) Barros, C., M. Berrios, and E. Herrera, J. Reprod. Fertil., 34 : 547-549. 1973.

11) Yanagimachi, R. and N. Usur, Exp. Cell. Res., 89: 161-174. 1974.

12) Yanagimachi, R. and C.A. Mahi, J. Reprod. Fertil,, 46 : 49-54. 1976 .

13) Barros, C. and M. Berrios, J. Exp. Zool., 201 : 6572. 1977.

14) MAHI, C.A. and R. YANAGIMÁCHI, J. Exp. Zool., 196 : 189-196. 1976.

15) Phill.tps, D.W., J. Cell. Biol, 53 : 561-573. 1972.

16) Fraser, L.E., J. Exp. Zool., 202 : 439-444. 1977.

17) Aonuma, S., M. OKabe, M. KaWaguchi and $Y$. KIsHI, Chem. Pharm. Bull. Jpn,, 28 : 1497-1502. 1980.

18) Cooper, G.W., J.W. OVERStReEt and D.F. Katz, Gamete. Res., 2 : 35-42. 1979.

19) Overstreet, J.W. and G.W. Cooper, J. Reprod. Fertil., 55 : 53-59. 1979.

20) Overstreet; J.W., D.F. Katz and L.L. Johnson, Biol. Reprod., 22 : 1083-1088. 1980.

21) Shams-Borhan, G. and R.A.P. Harrison, Gamete. Res., $4:$ : 407-432. 1981.

22) Cummins, J.M., Gamete. Res., $6: 53-63.1982$.

23) Lambert, H., Gamete. Res., $4: 525-533.1981$. 


\title{
Goat Sperm Life after Acrosome Reaction
}

24) Fleming, A.D., R. Yanagimachi and H. YanagiMACHI, J. Reprod. Fertil., 63 :.509-514. 1982.

25) Yanagimachi, R., in Fertilization and Embryonic Development In Vitro. (MastrolanN, L. and J.D. BigGers, eds.) 81-182. Plenum Press. New York. 1981.

26) YanagimachI, R., Biol. Reprod., 13 : 519-526. 1975.

27) Fraser, L.E. and P.J. Quinn, J. Reprod. Fertil., 61 : 25-35. 1981.

28) Fleming, A.D. and R. YANAGimachl, J. Exp. Zool., 220: 109-115. 1982.

29) Kinsey, W.H., G.K. Segall and W.J. Lennarz, Dev. Biol., 71 : 49-59. 1979.

30) VacQuiRe, V.D., Dev. Growth. Diff., $21: 61-69$.
1979.

31) Bou, S. and A. HanadA, Jpn. J. Anim. Reprod., 31 : 115-121. 1985.

32) HaNADA, A., Jpn. J. Anim. Reprod., 27 : 123-125. 1981.

33) Sutherland, E.W. and T.W. Rall, J. Biol. Chem., 232 : 1077-1091. 1958.

34) Butcher, R.W. and E.W. Sutherland, J. Biol. Chem., $237: 1244-1250.1962$.

35) Austin, C.R., Proc. Roy. Soc. Med., 67 : 925-927. 1974.

36) Sertz, H.M. Jr, G. ROCHA, B.G. BRACKeTt and L. Mastrolanni, Jr, Fertil. Steril., 21 : 325-328. 1970.

\section{ヤギ先体反応精子の運動能，生存能および 卵子侵入能保持時間}

\author{
楠 比呂志・阪上守人*・原山 洋・ \\ 加藤征史郎 ${ }^{*}$ - 荻田 淳* \\ 神户大学自然科学研究科, \\ * 神戸大学農学部，神戸市 657
}

\begin{abstract}
先体反応誘起後のヤギ精子の運動能, 生存能术よび透明帯除去ハムスタ一卵子への侵入能保持時間を 調べた．また，これらの特性に対するカフェインおよびイミダソールの影響についてあ険討した。 ヤギ 射出精子を洗浄後, 密封ガラ又管内において $39.5^{\circ} \mathrm{C} て ゙ 2$ 時間加温して先体反応を誘起した. ついで, これらの精子を $\mathrm{BO}$ 液, カフェイン添加 BO 波またはイミダゾール添加 BO 液に再浮遊して $37^{\circ} \mathrm{C} て ゙ 5$ 時間加温し，その間の運動性および生存性の変化を経時的に調べた．また，BO 液またはイミダゾール 添加 BO 液中に再浮遊直後の精子あるいは各媒液中で 3 時間加温した精子を透明帯除去ハムスター卵 子とともに $37^{\circ} \mathrm{C}$ でさらに 5 時間培養し，その間の卵子への精子の侵入状況を経時的に調べた．得られ た結果の概要は以下の通りである，1）ヤキ精子では先体反応誘起の前と後で運動様式が異なり, 誘起 後の精子はム千振り様の運動を行なった．2）先体反応誘起後のヤギ精子の運動能扰よび生存能は誘起 前に比べて著しく低下した，3）ヤギ先体反応精子の透明帯除去ハムスター卵子への侵入能保持時間は 3 時間以内であった．4）精子浮遊液へのイミダゾールの添加はヤギ先体反応精子の運動能および生存 能の維持ならびに透明帯除去ハムスター卵子への侵入能保持時間の延長に有効であった。一方, カフェ インの添加は運動性の一時的な付活には有効であったが，運動能および生存能の維持に対してはむしろ 有害であった.
\end{abstract}

日畜会報, $61(7) ： 640-647,1990$ 